Article

\title{
Energy Minimisation in a Protected Cropping Facility Using Multi-Temperature Acquisition Points and Control of Ventilation Settings
}

\author{
Premaratne Samaranayake ${ }^{1, *(D)}$, Chelsea Maier ${ }^{2}$, Sachin Chavan ${ }^{3}$, Weiguang Liang ${ }^{2}$, Zhong-Hua Chen ${ }^{3,4}$, \\ David T. Tissue $^{3}$ (D) and Yi-Chen Lan ${ }^{1, *(D)}$ \\ 1 School of Business, Western Sydney University, Penrith, NSW 2751, Australia \\ 2 National Vegetable Protected Cropping Centre, Western Sydney University, Penrith, NSW 2751, Australia; \\ C.Maier@westernsydney.edu.au (C.M.); W.Liang@westernsydney.edu.au (W.L.) \\ 3 Hawkesbury Institute for the Environment, Western Sydney University, Penrith, NSW 2751, Australia; \\ S.Chavan@westernsydney.edu.au (S.C.); Z.Chen@westernsydney.edu.au (Z.-H.C.); \\ D.Tissue@westernsydney.edu.au (D.T.T.) \\ 4 School of Science, Western Sydney University, Penrith, NSW 2751, Australia \\ * Correspondence: P.Samaranayake@westernsydney.edu.au (P.S.); Y.Lan@westernsydney.edu.au (Y.-C.L.)
}

\section{check for} updates

Citation: Samaranayake, P.; Maier, C.; Chavan, S.; Liang, W.; Chen, Z.-H.; Tissue, D.T.; Lan, Y.-C. Energy Minimisation in a Protected Cropping Facility Using Multi-Temperature Acquisition Points and Control of Ventilation Settings. Energies 2021, 14, 6014. https://doi.org/10.3390/ en14196014

Academic Editor: Christopher Micallef

Received: 20 August 2021

Accepted: 18 September 2021

Published: 22 September 2021

Publisher's Note: MDPI stays neutral with regard to jurisdictional claims in published maps and institutional affiliations.

Copyright: (c) 2021 by the authors. Licensee MDPI, Basel, Switzerland. This article is an open access article distributed under the terms and conditions of the Creative Commons Attribution (CC BY) license (https:// creativecommons.org/licenses/by/ $4.0 /)$.

\begin{abstract}
Energy management in protected cropping is critical due to the high cost of energy use in high-tech greenhouse facilities. The main purpose of this research was to investigate the optimal strategy to reduce cooling energy consumption, by regulating the settings (opening/closing) of either vents or curtains during the day, at the protected cropping facility at Western Sydney University. We measured daily changes in air temperature and energy consumption under four treatments (open/closed combinations of vents and shade screens) and developed an optimal cooling strategy for energy management using multi-temperature acquisition points at different heights within a greenhouse compartment. The optimal treatment (vents open/curtains closed) reduced energy load at the rooftop, thereby maintaining a desirable plant canopy temperature profile, and reducing cooling energy. Daily energy consumption was lowest for vents open/curtains closed $(70.5 \mathrm{kWh})$ and highest for vents closed/curtains open $(121 \mathrm{kWh})$. It was also found that delaying the operation of opening and closing of vents and curtains until the plant canopy temperature reached $25^{\circ} \mathrm{C}$ reduced cooling energy consumption and decreased heating energy consumption in the morning (e.g., 08:00 to 10:00). The estimated savings of $1.83 \mathrm{kWh}$ per $1^{\circ} \mathrm{C}$ cooling between the optimal (vents open/curtains closed) and least optimal (vents closed/curtains open) conditions had the potential for significant energy savings at $494 \mathrm{kWh}$ per ${ }^{\circ} \mathrm{C}$ over a crop cycle of nine months in warm weather conditions. However, selection of the optimal cooling strategy utilising control of vents and curtains must also account for the impact from other greenhouse environmental factors, including light, humidity, and $\mathrm{CO}_{2}$ concentration, which may be crop specific.
\end{abstract}

Keywords: temperature; greenhouse control systems; energy consumption; cooling energy; roof-top vent; energy curtain

\section{Introduction}

Sustainable food production within the broader agri-food supply chain is one of the major considerations for growers, consumers, and governments, from several perspectives. Areas of concern for sustainable food production include environmental impacts, food security, and safety, water and energy consumption. These concerns have been exacerbated due to the rapid growth of the world population leading to increased fresh food demand [1], climate change impacting food production and supply [2], business competitiveness, the sustainability of economic development, and social well-being [3]. Overall, these factors have contributed to significant changes to current food production and agri-food 
supply chains around the globe, including an increased level of protected cropping of key horticultural crops (e.g., tomato, capsicum, cucumber, lettuce, and eggplant) and a growing number of new crops under protected cropping in many parts of the world [1-5].

Extreme climate events, which are more prevalent with climate change, have profound impacts on horticultural production across the globe. Farmers must contend with droughts, heatwaves, and floods, and are constantly seeking alternative methods that can sustain production during these events [6]. Protected cropping offers independent climate control through automated cooling, heating, and fertigation mechanisms to maximise the yield potential and quality of crops [5]. One of the characteristics of protected cropping is the use of advanced greenhouse technologies for year-round production of high-quality produce with better utilization of various resources, particularly scarce resources including water, fertilizer, and energy, irrespective of climate and weather conditions [1,7-9]. Main drivers for protected cropping include creating sustainable production and consumption patterns [3], meeting an increased demand for a wide range of products under constrained resources [9], promoting sustainable waste management strategies, and considering economic, environmental and social aspects [10].

Substantially high yield and consistently high quality of fresh produce are the two fundamental indicators attracting an increased number of farmers to transform from field cropping to protected cultivation. Nevertheless, relatively high ongoing operational expenses are notably influencing the adoption of the protected cropping transformation. One of the primary costs in protected cropping is energy consumption for maintaining climate conditions in greenhouses and indoor cropping systems. The controlled climate provides an environment that is most desirable for plant growth and health. In Australia and warm climate areas, cooling is the most significant energy use component in running a protected cropping facility, due to more solar radiation and higher temperature than in cooler temperate regions [11]. Many researchers across continents have compared the energy use between open field cultivation and protected cropping [12-15]. They have also investigated various heat-filtering film coverings for greenhouse crop production [16-18] and developed prediction models of protected cropping energy consumption [19-22]. These investigations have shown consistent results in response to the effective management of energy consumption through temperature prediction, the introduction of new greenhouse covering materials, glass coatings, and the use of renewable energy sources. However, these approaches require additional investment to validate the effectiveness of management in reducing energy consumption in the greenhouse operation. Recently, using experimental trials, refs. $[16,18]$ concluded that "Smart Glass" film (commercially available window film ULR-80 that blocks UV and higher light wavelengths which are not used for plant growth but contribute to heat generation) applied to the roof and walls of a greenhouse increase energy and resource use efficiency, without affecting fruit quality. The energy saving was accompanied by certain levels of yield reduction in both eggplant and capsicum crops $[16,18]$. However, there is still a lack of research investigation on energy analysis in protected cropping from adjustable ventilation and energy-efficient design perspectives.

This study aims to investigate energy consumption, and to propose guidelines and strategies for optimal energy management through multi-point temperature acquisition, in a high-tech greenhouse using existing climate control systems. The main objectives are to (i) examine the differences of temperature captured through the multi-point acquisition method, (ii) determine suitable timeframes for the greenhouse rooftop ventilation operation, which consequently will delay activating the more expensive cooling system, and hence (iii) reduce cooling energy consumption in high-tech greenhouses. In addressing this research gap, we compared energy consumption under four different open/closed combinations of vent and shade screen positions, as a function of the temperature difference between external and internal temperature measured at different locations in the glasshouse. 


\section{Materials and Methods}

\subsection{Greenhouse Hardware and Software}

This study used experimental data to investigate the current energy consumption for comparison with the proposed multi-temperature acquisition points system for optimum energy management in a protected cropping facility at Western Sydney University (WSU). Currently, for temperature control of a crop, the Priva system (Priva, The Netherlands) uses one temperature sensor that is positioned at the top of the crop to trigger ventilation and mechanical cooling methods in the greenhouse to modulate air temperature to meet desired settings. However, this measurement does not incorporate the cooler temperatures below the canopy or the hotter temperatures at the roof ridge close to the vents. By understanding the nature of the whole compartment temperature profile, predictive models can be developed to open vents at ideal times for temperature control and thus not rely on mechanical cooling methods that are energy expensive. The experimental data collected from the Priva system are analysed to quantify the current energy consumption and possible energy reduction if the greenhouse roof ventilation is set to operate/trigger, based on temperatures captured at both the rooftop and the gutter levels. In this case, temperature data were collected by setting multi-temperature acquisition points through hobo pendant temp/light data loggers (UA-002-08, Onset, MA, USA). Measured temperature data were used to gauge the possible delay of cooling the greenhouse compartment by opening the vents earlier with the trigger of the rooftop level temperature, thereby reducing the temperature inside the facility that directly influences the cooling energy consumption. Priva is a climate and process-control system which uses a dedicated climate and process computer, Priva Connext 909 (Priva, The Netherlands), to actuate motors, pumps, and fans. Input and output data are logged as 5-min averages and automatically uploaded to the Hawkesbury Institute for the Environment (HIEv) computer system monthly, with the key parameters defined in Appendix A (Table A1).

The energy consumption under current settings and delayed cooling strategy is evaluated using four different combinations of vent and shade screen positions (closed and open) during the day. Daily and average energy consumption across four combinations are compared as a basis for developing an optimal cooling strategy for energy management. An optimal cooling strategy for energy management using multi-temperature acquisition points for opening/closing of vents and shade screens could be used to extend the overall energy consumption profile of the selected protected cropping facility $[16,23]$. These studies form the basis for setting the opening or closing of vents, using the most reliable temperature measurements within the facility, to reduce energy costs during $6-9$ months of cropping cycles.

\subsection{Research Design}

The research design was to measure the temperature at the WSU protected cropping facility using multi-temperature acquisition points over a selected period. Energy consumption is a significant portion of the overall cost of running the greenhouse facility. Thus, the research is designed to measure the temperature at three levels (rooftop ( $7 \mathrm{~m}$ from the floor), mechanical cooler (4.2 $\mathrm{m}$ from the floor), and gutter (1.5 $\mathrm{m}$ from the floor)), compared to only gutter level measurement currently being used to trigger the opening of vents. Details of the greenhouse facility, areas selected for the experiment, and timing of temperature measurement with the period selected are outlined next. Figure 1A shows a schematic diagram of the protected cropping facility with positions of temperature measurement at three of the previously mentioned levels: gutter, mechanical cooler, and rooftop. The temperature difference between Gutter level and Rooftop level during the day is compared as a basis for developing an optimal cooling strategy using optimum timeframes for saving excessive cooling energy consumed by current settings for opening and closing of vents and shade screens using the gutter level temperature along with the energy used on cooling to get rid of the excessive heat build-up due to closed vents. To develop an optimal cooling strategy and guidelines for optimum timeframes of opening and closing of vents and 
shade screens based on the temperature difference between external and rooftop level, daily and average energy consumption, and the temperature (both gutter and rooftop levels) during the day at the protected cropping facility were measured over four different open/closed combinations of vents and shade screens. The temperature inside the facility at three heights (gutter, mechanical cooler, rooftop) is illustrated in Figure 1A, which is measured and compared with the daily outside temperature for evaluating the cooling energy consumption under current settings and energy savings through multi-acquisition temperature settings. While indoor or outdoor air pressure was similar, the external wind speed was measured by a weather station attached to the outside of the glasshouse and the data was incorporated in the Priva control system operation. Details of the research design, experiment configuration, data collection, and analysis are discussed next.
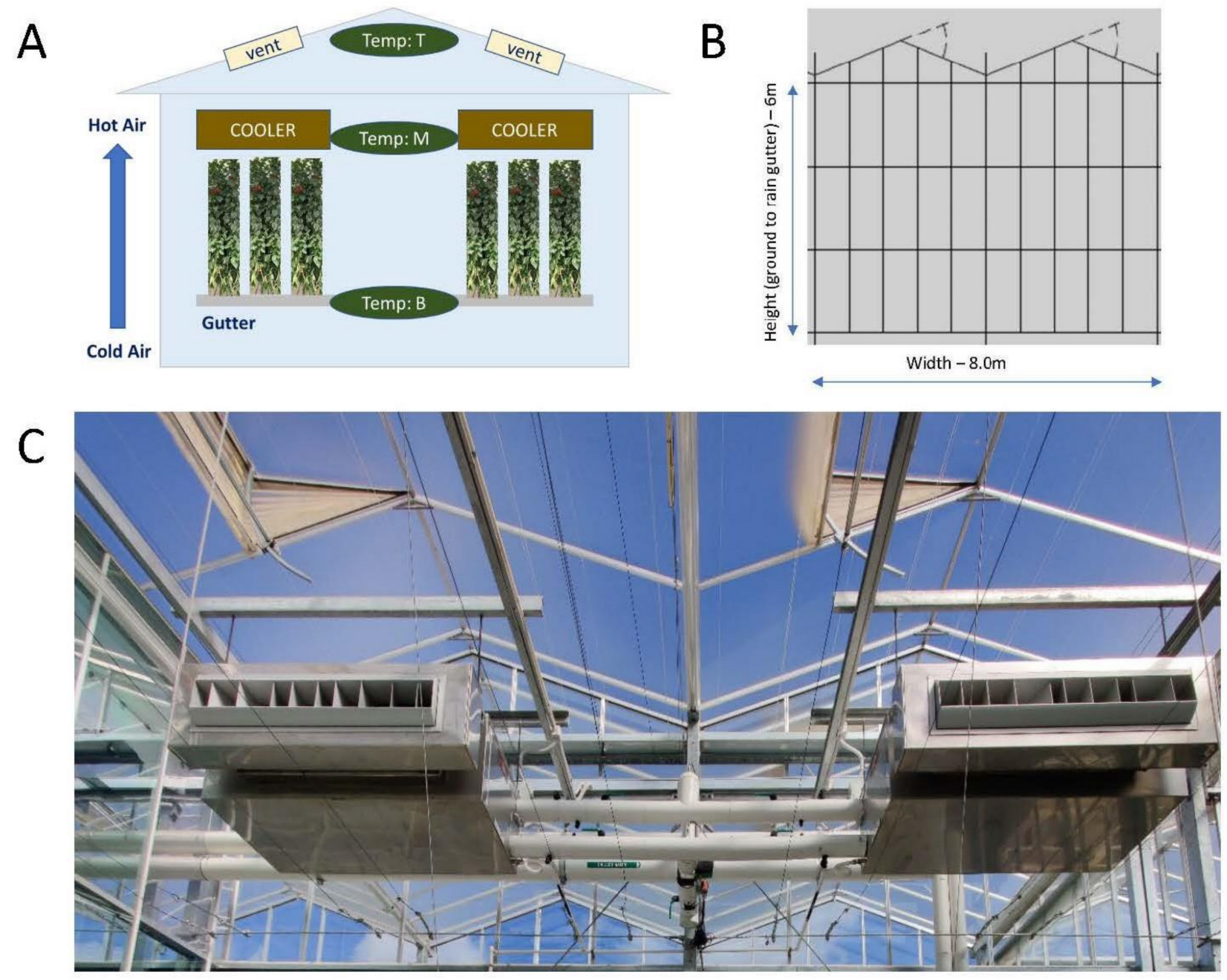

Figure 1. Research design and experimental configuration. (A) Schematic diagram of positions of the temperature sensors inside one of the experimental compartments. (B) The northwestern side of the greenhouse $(13.6 \mathrm{~m} \mathrm{~L} \times 8.0 \mathrm{~m} \mathrm{~W} \times 6 \mathrm{~m} \mathrm{H}$ (ground to rain gutter), depicting that both roof vents open toward the southwest. (C) Two mechanical coolers used for temperature control in the compartment.

\subsection{Experimental Configuration}

The study was conducted at the Western Sydney University's National Vegetable Protected Cropping Centre, a Venlo-style state-of-the-art research, education, and training greenhouse facility located in the Hawkesbury of Western Sydney, NSW. The facility is $1800 \mathrm{~m}^{2}$ consisting of eight $105 \mathrm{~m}^{2}$ research compartments and one $400 \mathrm{~m}^{2}$ teaching compartment. Climate and irrigation monitoring, control, and automation are managed via 
Priva hardware and software (Priva, The Netherlands). One of the research compartments $(\mathrm{L}=13.6 \mathrm{~m}, \mathrm{~W}=8.0 \mathrm{~m}$, and $\mathrm{H}=6 \mathrm{~m})$ was used for this experimental study. The research compartment consists of two roof ridge peaks each with continuous vents spanning the length of the compartment opening toward the southwest as illustrated in Figure 1B. When vents are fully open, the vent hole size is $10.0 \mathrm{~m} \times 1.0 \mathrm{~m}$. In addition, shade screens (Harmony 5045, Svenssons, Sweden) are used in this compartment. The function of the shade screen is to provide shading by reducing photosynthetically active radiation (PAR) by $50 \%$ indirect light and $54 \%$ diffuse light and thus reduce radiative heating.

The compartment (Room 3) does not use a conventional pad-fan system for cooling which is common in many greenhouses. Instead, the compartment implements cooling via two fan coil unit mechanical coolers (Figure 1C) consisting of a fan that pulls air over a coil fed with $6{ }^{\circ} \mathrm{C}$ water via a cold water storage tank, chilled by a chiller. Each cooler has a capacity of $30 \mathrm{~kW}$ at $28{ }^{\circ} \mathrm{C}$ air temperature, $80 \% \mathrm{RH}$ (relative humidity), and $6{ }^{\circ} \mathrm{C}$ cooling water lifted to $16^{\circ} \mathrm{C}$. The $6{ }^{\circ} \mathrm{C}$ water is added into the circulation system of the fan with a modulating valve. The amount of $6{ }^{\circ} \mathrm{C}$ water added to the system depends on the desired temperature of the room. Each compartment has two continuous vents, that span $11 \mathrm{~m}$ on each roof ridge. When the vents are open $100 \%$, the area open for air exchange is $11 \mathrm{~m} \times 0.7 \mathrm{~m}$ per vent. The shade screen is separated into three sections that concertina to $0.5 \mathrm{~m}$ long $\times 8 \mathrm{~m}$ wide when contracted and when these three sections are expanded they span the width and length of the whole compartment and are installed at $6 \mathrm{~m}$ from the floor.

\subsection{Research Compartment Parameters, Settings, and Climate Strategy}

The experiment was run over 4 time periods ( 3 days each) from 20 May to 31 May 2021; these days were selected because weather conditions were similar during the entire experimental period. The shade screen and vent settings for each period are outlined in Table 1. For instance, Period 1 covers the first 3 days, and both vents and shade screens were fully opened throughout the experiment period. Priva data and energy readings were captured from 08:00 to 17:00 each day throughout the entire experiment across 4 periods. During periods in which vents were fully open, the system could override the open setting to close the vents in the event of a storm as a protective strategy.

Table 1. Experimental periods—shade screen and vent status in each period in the greenhouse compartment.

\begin{tabular}{|c|c|c|c|c|c|c|c|}
\hline \multicolumn{2}{|c|}{$\begin{array}{c}\text { Period 1: } \\
\text { May } 20 \text { (08:00)-22 (17:00) }\end{array}$} & \multicolumn{2}{|c|}{$\begin{array}{c}\text { Period 2: } \\
\text { May } 23 \text { (08:00)-25 (17:00) }\end{array}$} & \multicolumn{2}{|c|}{$\begin{array}{c}\text { Period 3: } \\
\text { May } 26(08: 00)-28 \text { (17:00) }\end{array}$} & \multicolumn{2}{|c|}{$\begin{array}{c}\text { Period 4: } \\
\text { May 29 (08:00)-31 (17:00) }\end{array}$} \\
\hline Shade screen & Vent & Shade screen & Vent & Shade screen & Vent & Shade screen & Vent \\
\hline Status & Status & Status & Status & Status & Status & Status & Status \\
\hline Open & Open & Open & Closed & Closed & Open & Closed & Closed \\
\hline
\end{tabular}

The research compartment was set to maintain temperatures within ranges at particular times of day (Table 2). To be specific, the temperature is set to activate heating if it reaches $21^{\circ} \mathrm{C}$ or below between 08:00 and 17:00 (the first time bracket). During the second time bracket (5:00 p.m. to 00:00), the heating is set to activate at $15^{\circ} \mathrm{C}$ or below. In the third time bracket (00:00 to $08: 00), 16^{\circ} \mathrm{C}$ is the set temperature to activate the heating. With regard to the cooling strategy, temperatures are set to $25^{\circ} \mathrm{C}, 17^{\circ} \mathrm{C}$, and $18{ }^{\circ} \mathrm{C}$ for the respective time brackets. No humidity control was utilised during the course of the experiment.

In terms of the climate strategy, two categories (heating and cooling) of climate settings are applied to determine a desired gutter level temperature in three specific time brackets. In general, when temperatures fall below heating temperatures, heating is activated. When temperatures rise above cooling temperatures, mechanical coolers are activated. 
Table 2. Summary of variables for the experiment in the greenhouse compartment.

\begin{tabular}{ll}
\hline Experiment Variable & Description \\
\hline Date & Experiment period from 20 May to 31 May 2021 \\
Time & 15 min interval from 08:00 to 17:00 each day \\
Temp_B $\left({ }^{\circ} \mathbf{C}\right)$ & Temperature captured at the gutter level \\
Temp_M $\left({ }^{\circ} \mathbf{C}\right)$ & Temperature captured at the mechanical cooler level \\
Temp_T $\left({ }^{\circ} \mathbf{C}\right)$ & Temperature captured at the rooftop level \\
Temp_S $\left({ }^{\circ} \mathbf{C}\right)$ & Set Temperature at the facility as the desired temperature \\
Temp_Outside $\left({ }^{\circ} \mathbf{C}\right)$ & Outdoor temperature captured from the weather station \\
& installed above the northwestern corner of the facility \\
Instantaneous energy reading_Cooler $\mathbf{( k W h )}$ & Energy usage measured in kilowatt-hour for cooling units $(>0$ \\
& active; 0 inactive) for each time period $(15$ min) \\
\hline
\end{tabular}

To monitor the compartment temperatures, the temperature sensors were connected and monitored with the Priva system, they were located at the growing gutter level of the room, and data were logged every $5 \mathrm{~min}$. Also, a profile of three hobo pendant temp/light data loggers (UA-002-08, Onset, MA, USA) was installed. One data logger located at the Priva temperature sensor height, a second at the height of the mechanical cooler, and a third at the rooftop on the western most ridge of the room. These loggers logged temperature every 15 min from the hour. Outside temperature, multi-point temperatures within the greenhouse facility and energy readings were extracted from Priva system and hobo pendant temp/light data loggers across four experimental periods. Table 2 summaries the variables and the corresponding descriptions for this study.

\section{Results}

\subsection{Analysis of Overall Energy Consumption under four Different Vent/Shade Screen Configurations}

The daily average energy consumption of each experimental period was evaluated using the recorded instantaneous energy reading (Table 3). It is noted from energy consumptions that Period 2 has recorded the highest daily and average energy consumptions, followed by Period 4. As expected, relatively high energy consumptions during these two periods could be attributed to the condition of vents being closed during both periods. The only difference between these two periods was the status of the shade screens. Although Period 4 had the shade screens closed, compared to the shade screens open in Period 2, the average energy consumption in Period 2 is about $60 \%$ higher than that of Period 4 . This is a significant increase in energy consumption, attributed mainly to the shade screen status (open vs closed). Based on the daily energy consumption excluding day 2 (given there is no cooling activated in Period 1), it can be noted that Period 2 has the highest daily average energy consumption, while Period 3 has the lowest energy consumption. This suggests that the best combination for efficient energy consumption from the cooling perspective is the combination of the shade screen-closed and vent-open as set during Period 3 experiments. This is further supported/evidenced by/from the lowest energy consumption under the exact opposite combination at Period 2 (shade screens open and vents closed).

The analysis of energy consumption (Table 3) shows significant differences in daily average energy consumptions, including the highest daily average of $121 \mathrm{kWh}$ using vent-closed/shade screens open and the lowest daily average of $70.5 \mathrm{kWh}$ using ventopen/shade screens-closed. When the effect of vent on energy consumption (Periods 1 and 2) is compared with that of the shade screen on energy consumption (Periods 2 and 3), there is a significant difference in energy consumption, influenced by the effect of vent opening and closing. The following sub-sections provide analysis of temperature and energy data over four experimental periods. 
Table 3. Daily and average energy consumption $(\mathrm{kWh})$ in different statuses of vents and shade screens in the greenhouse compartment.

\begin{tabular}{ccccc}
\hline Day of the Period & $\begin{array}{c}\text { Period 1 } \\
\text { Shade Screen/Vent } \\
\text { (Open/Open) }\end{array}$ & $\begin{array}{c}\text { Period 2 } \\
\text { Shade Screen/Vent } \\
\text { (Open/Closed) }\end{array}$ & $\begin{array}{c}\text { Period 3 } \\
\text { Shade Screen/Vent } \\
\text { (Closed/Open) }\end{array}$ & $\begin{array}{c}\text { Period 4 } \\
\text { Shade Screen/Vent } \\
\text { (Closed/Closed) }\end{array}$ \\
\hline Day 1 & 79 & 123 & 80 & 78 \\
\hline Day 2 & 0 & 95 & 62 & 41 \\
\hline Day 3 & 79 & 119 & 61 & 70.33 \\
\hline $\begin{array}{c}\text { Average energy } \\
\text { consumption }\end{array}$ & 52.67 & 112.33 & 70.5 & 85 \\
\hline $\begin{array}{c}\text { Average (Day 1 and } \\
\text { Day 3) }\end{array}$ & 79 & 121 & 6.17 & 15.21 \\
\hline Standard Error & 26.33 & 8.74 & \\
\hline
\end{tabular}

\subsection{Analysis of Temperature and Energy during Period 1}

During this period, both vents and shade screens were forced to open. It can be noted from Figure 2 that the rooftop level temperature closely aligns with the gutter level temperature across the experiment period, except for 3-4 $\mathrm{h}$ between late morning and early afternoon on day 1 and day 3 . Hence, the mechanical coolers were activated during the higher temperature gap with a total energy consumption of $158 \mathrm{kWh}$. Due to the cold temperature on day $2\left(\min 6.88^{\circ} \mathrm{C}\right.$, $\left.\max 17.18^{\circ} \mathrm{C}\right)$, the gutter level temperature was maintained below $25^{\circ} \mathrm{C}$, hence the cooling units were inactive.

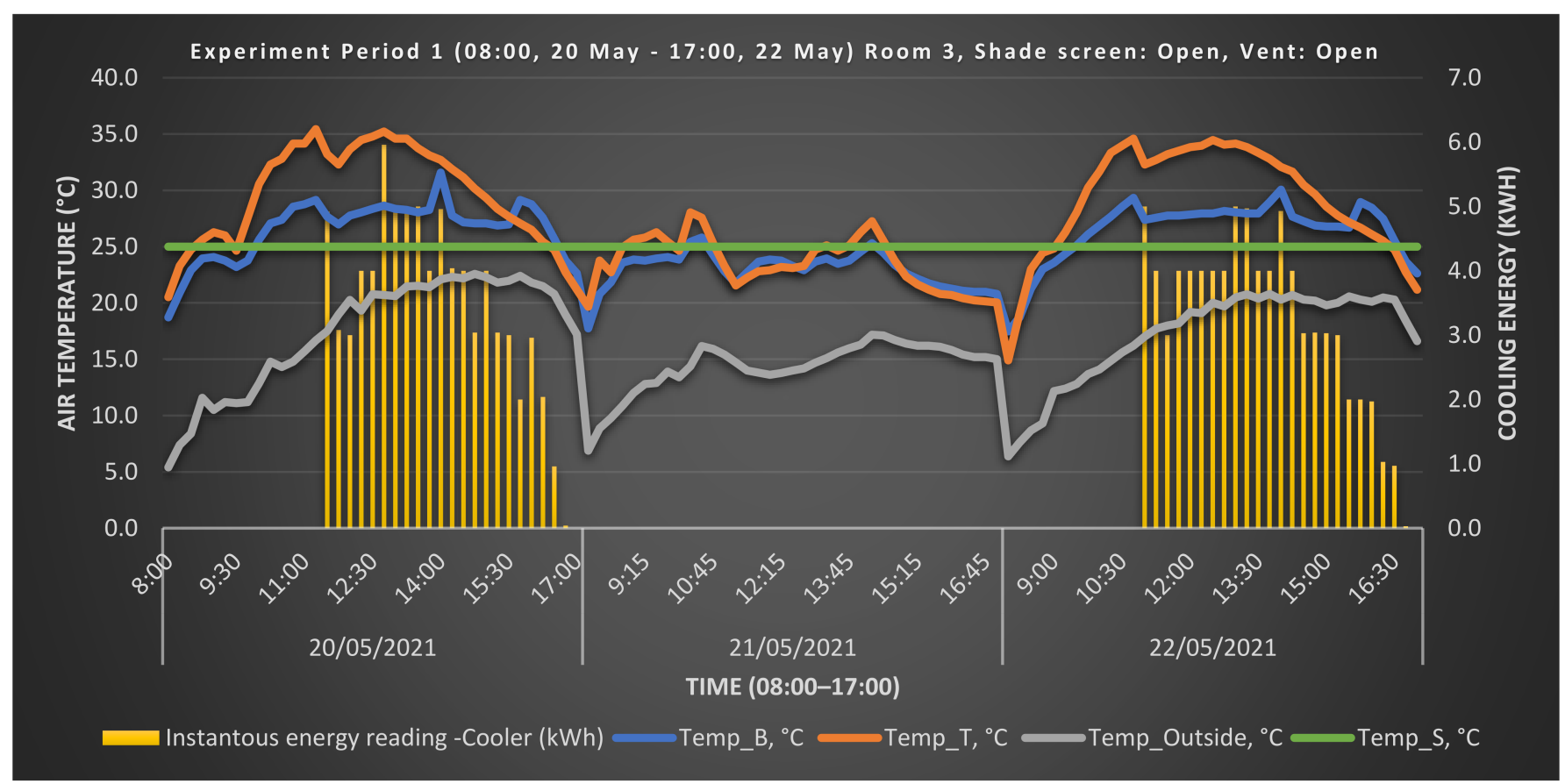

Figure 2. Temperature and energy use in different vent and shade screen status in experimental Period 1. Air temperatures collected at the base (B), top (T), and outside are depicted in blue, orange, and white lines respectively. Energy use measured by mechanical coolers is depicted over time using yellow bars along with air temperatures.

\subsection{Analysis of Temperature and Energy during Period 2}

In this experimental period, the shade screen was open, but the rooftop vents were forced to close. As indicated in Figure 3, the rooftop level temperature was noticeably higher than the gutter level temperature throughout the period, especially between late 
morning and early afternoon with the recorded maximum temperature gap of $10.31{ }^{\circ} \mathrm{C}$ (rooftop: $38.27^{\circ} \mathrm{C}$ vs. gutter: $27.96^{\circ} \mathrm{C}$ ). The gutter level temperature in $77 \%$ (or $86 / 111$ timeslots throughout the period) of the period was recorded higher than the set cooling activation temperature $\left(25^{\circ} \mathrm{C}\right)$, hence the cooling units were activated in $73 \%$ of the experiment period. This accounts for $337 \mathrm{kWh}$ electricity consumption for cooling, therefore the average daily energy consumed for cooling activation in Period 2 is $112.33 \mathrm{kWh}$.

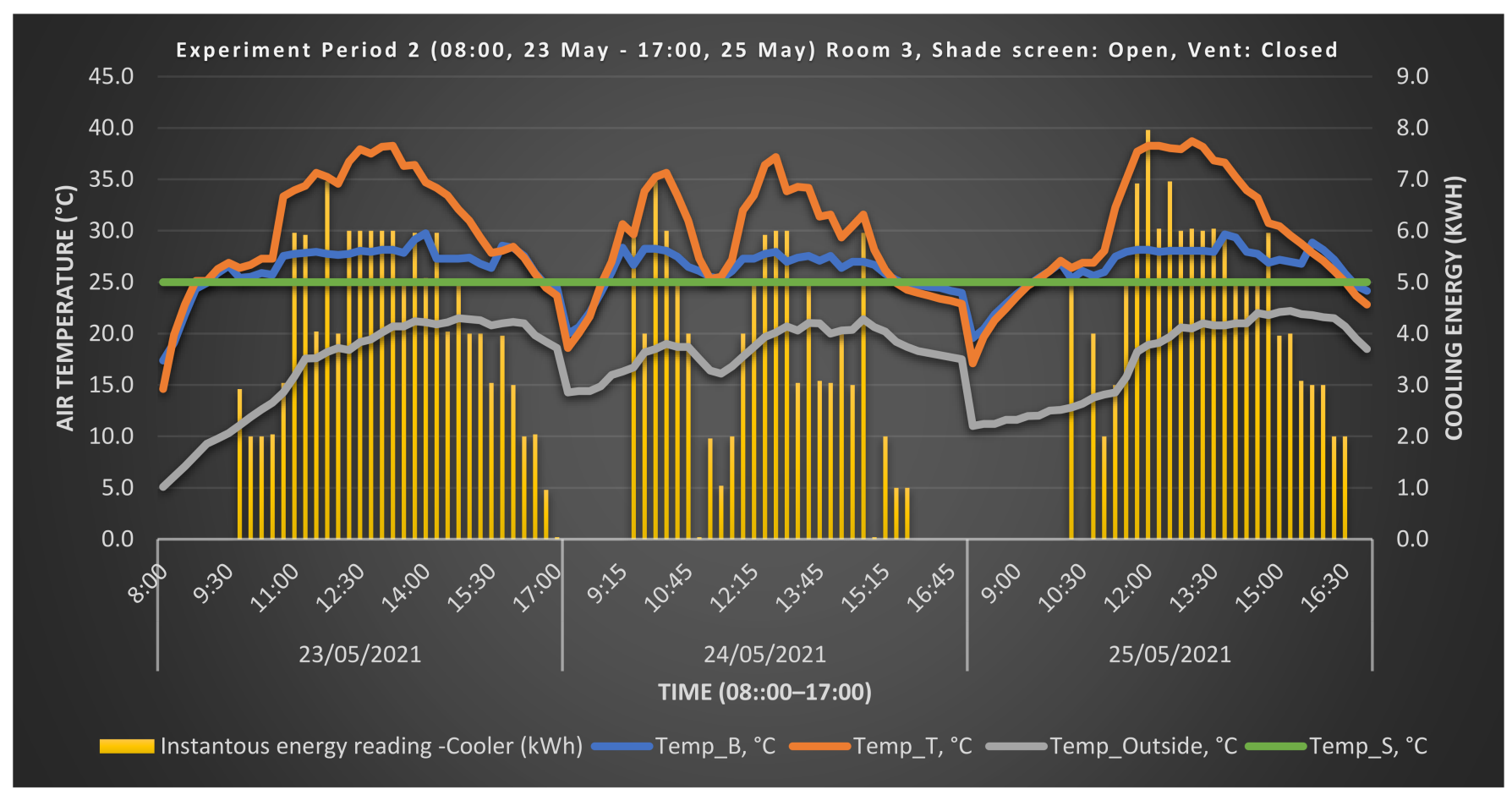

Figure 3. Temperature and energy use in different vent and shade screen status in experimental Period 2. Air temperatures $\left({ }^{\circ} \mathrm{C}\right)$ collected at the base (B), top (T), and outside are depicted in blue, orange, and white lines, respectively. Energy use $(\mathrm{kWh})$ measured by mechanical coolers is depicted over time using yellow bars along with air temperatures.

\subsection{Analysis of Temperature and Energy during Period 3}

In this period, the shade screen position remained closed while the vents were forced to open. Given the shade screen was closed, the cumulated heat through the greenhouse effect was trapped and unable to flow through the vents as fast as when the shade screen was opened. Hence $75 \%$ of the recorded gutter level temperature timeslots were higher than $25^{\circ} \mathrm{C}$, which triggered the cooling and subsequently consumed $203 \mathrm{kWh}$ through the period or an average $67.66 \mathrm{kWh}$ daily. Figure 4 shows the distribution of temperature and energy use during Period 3.

\subsection{Analysis of Temperature and Energy during Period 4}

In the last experiment period, both shade screens and vents were closed. It is observed that the total cooling energy consumption was $211 \mathrm{kWh}$. Although both shade screen and vents were closed, only $65 \%$ of the recorded gutter level temperature timeslots were over $25{ }^{\circ} \mathrm{C}$ due to the cold weather during the period (average $15.38{ }^{\circ} \mathrm{C}$ ). Figure 5 shows the distribution of temperature and energy use during Period 4. 


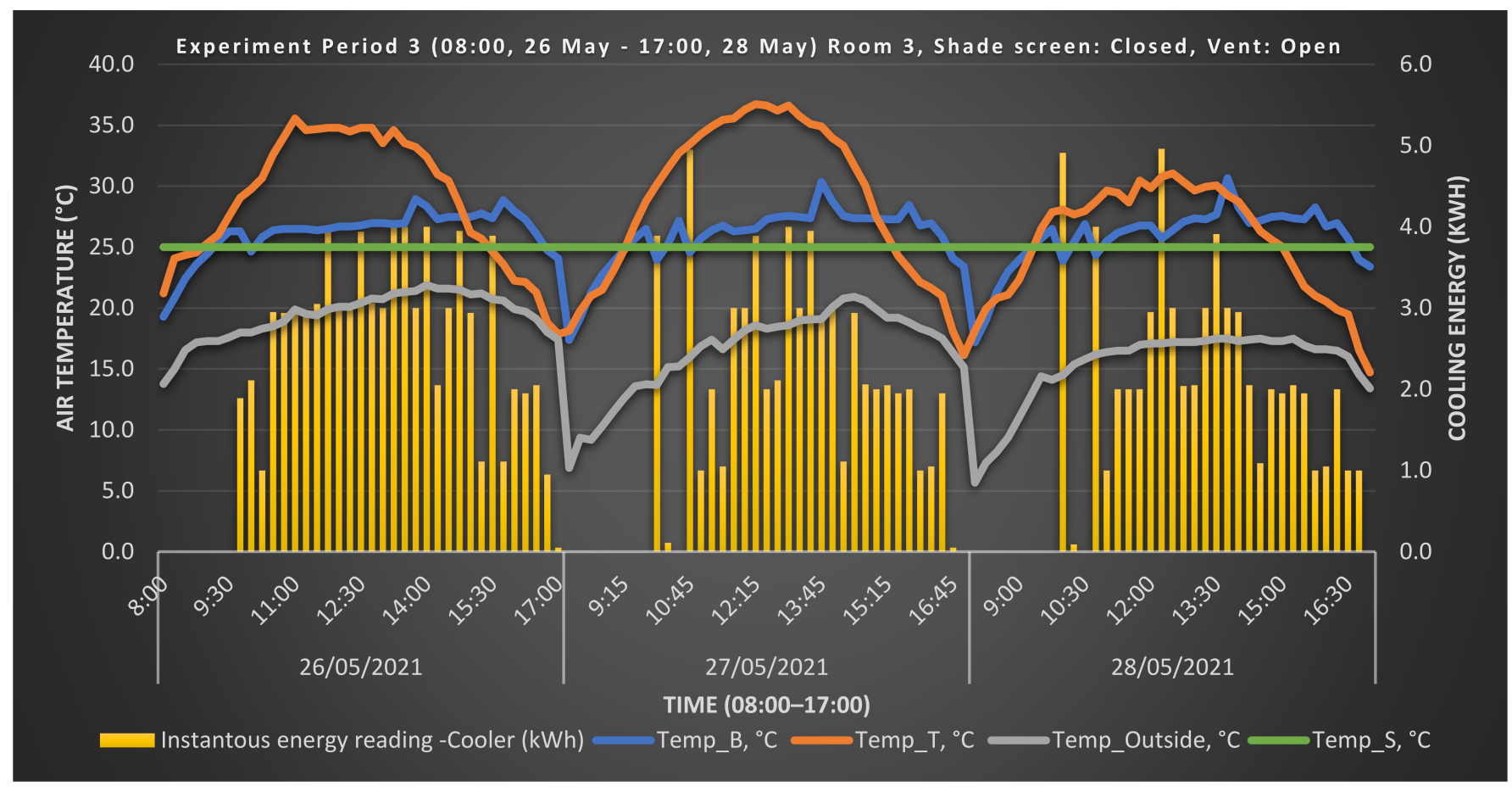

Figure 4. Temperature and energy use in different vent and shade screen status in experimental Period 3. Air temperatures $\left({ }^{\circ} \mathrm{C}\right)$ collected at the base (B), top (T), and outside are depicted in blue, orange, and white lines respectively. Energy use $(\mathrm{kWh})$ measured by mechanical coolers is dpeicted over time using yellow bars along with air temperatures.

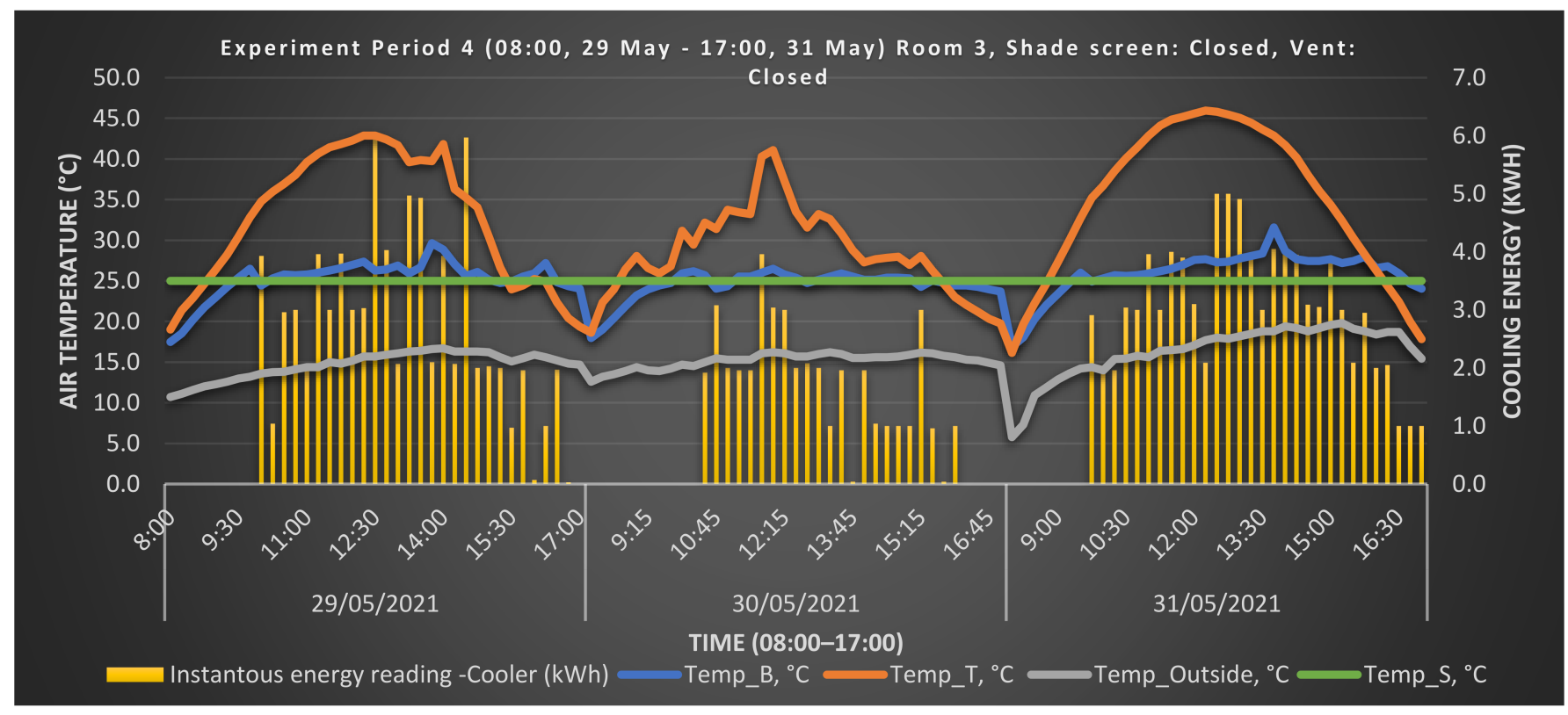

Figure 5. Temperature and energy use in different vent and shade screen status in experimental Period 4. Air temperatures $\left({ }^{\circ} \mathrm{C}\right)$ collected at the base (B), top (T), and outside are depicted in blue, orange, and white lines, respectively. Energy use $(\mathrm{kWh})$ measured by mechanical coolers is depicted over time using yellow bars along with air temperatures.

\subsection{Comparative Analysis of Energy Consumption and Potential Savings}

The temperature profile of the compartment was investigated as a basis for exploring the potential energy savings through identifying the best configuration of vents and shade screen, setting adjustable times of opening and closing of vents and shade screen, using the most appropriate temperature readings primarily from the rooftop and gutter positions. 
As expected from the weather forecast and shown in Figures 2-5, the outside temperature profile of each period (periods 1-4) is similar. Therefore, it is assumed that the impact of weather factors from the environment on energy consumption is negligible for comparative analysis of different periods. For the purpose of comparative analysis, only two of four configurations (Periods 2 and 3) used in the overall experiment are considered, since Period 2 (vents closed and shade screen open) and Period 3 (vents open and the shade screen closed) were identified as the worst and best configurations for cooling energy consumptions. The temperature profile of the facility at the rooftop and gutter levels are analysed to examine how significant the difference is between the temperatures measured at two levels. Figure 3 shows the temperature profile of the facility during Period 2, clearly indicating the differences in temperature between the two levels. Table A2 (Appendix B) shows basic descriptive statistics and ANOVA results. Figure 4 shows the temperature profile of the facility during Period 3.

Figure 4 shows a similar pattern of temperature distribution over three days, with the consistently higher temperature at rooftop level during most of the day, compared to that of gutter level. Furthermore, the rooftop temperature reaches $25^{\circ} \mathrm{C}$ between 08:00 and 09:00 stays above $25^{\circ} \mathrm{C}$ for most of the day before it goes below $25^{\circ} \mathrm{C}$ between 15:00 and 16:00 on the second and third days of the period. The temperature profile can be used to develop a benchmarking guide for the opening of vents and the closing of the shade screen using adjustable temperature settings to optimise the cooling energy consumption. The rooftop temperature was significantly different from the gutter level temperature (Table A4).

PAs shown in Figure 4, the temperature profile of the facility during Period 3 is similar to that of Period 2 (Figure 3). However, the average temperature gaps between gutter and rooftop levels in Period 3 (Table A3, Appendix B) show no significant difference. This suggests that Period 3 not only saves energy but also maintains a consistent temperature profile at the facility. It is also noted that the maximum rooftop temperature in Period 3 recorded $36.46^{\circ} \mathrm{C}$, which is $1.67^{\circ} \mathrm{C}$ lower than that in Period $2\left(38.13^{\circ} \mathrm{C}\right)$.

Comparison of the temperatures at two levels of the protected crop facility showed mixed results, depending on the combination of vents and shade screen open/closed configurations, particularly under two extreme conditions (Periods 2 and 3) tested. It was found that temperature at the rooftop level is significantly higher compared to that of gutter level during Period 2 (vents closed and shade screen open), leading to high cooling energy consumption. However, when these two temperatures were compared during Period 3 (vents open and shade screen closed), the difference is not significant. It is noted from energy consumption across four periods that the vents/closed condition is a significant factor for high cooling energy consumption.

To compare the energy consumption with the effect of opening and closing of vents and shade screen, the cooling energy consumption under two different combinations of vents/shade screen status were investigated. The potential energy savings through the selection of the best configuration of open/closed combination of vents and shade screen were estimated as a basis of further savings of cooling energy consumption using the adjustable settings for opening and closing of vents and shade screen.

As shown in Table A4 (Appendix B), on average, every hour can potentially save $5 \mathrm{kWh}$ during 8-h operations of vents/shade screen open/closed combinations considered. This equates to daily savings of $40 \mathrm{kWh}$. Since these potential cooling energy savings are estimated using two sets of experiments over a limited period (six days) under mild weather conditions (Autumn season) with a relatively smaller range of temperature difference between outside and inside, the cooling energy consumption over a longer period during much warmer seasons including summer needs to be considered. For this purpose, energy consumption per $1^{\circ} \mathrm{C}$ cooling is sought as a basis of benchmarking of the energy consumption of the selected facility. 


\subsection{Energy Consumption Benchmarking with Temperature Profile}

Since these savings are evaluated over mild weather conditions, it is important to set a benchmark of the energy requirement of $1{ }^{\circ} \mathrm{C}$ cooling so it could be used to predict cooling energy savings over a complete crop cycle that usually runs for six-eight months with a large variation of the outside temperature. For example, ref. [23] reported energy consumption of protected cropping of the capsicum production cycle and indicated the cycle of 247 days with a broader temperature range outside the facility, including a maximum temperature difference of $21.3^{\circ} \mathrm{C}$ between the internal and outside temperature.

Energy consumption per $1^{\circ} \mathrm{C}$ cooling is evaluated using two combinations of experiments (Periods 2 and 3 ) when outside daytime temperatures were relatively similar $\left(\sim 20^{\circ} \mathrm{C}\right)$. In both cases, hourly periods with zero cooling energy consumptions (e.g., 08:00 to 09:00 on each day of Periods 2 and 3) are excluded from the evaluation of hourly average energy consumption. To evaluate energy consumption per $1^{\circ} \mathrm{C}$ cooling, the average temperature difference between gutter level temperature (Temp_B) and Set Temperature $\left(25^{\circ} \mathrm{C}\right)$, and average hourly energy consumption during each period (Periods 2 and 3) were used. In the case of Period 2, the temperature difference of $2.12{ }^{\circ} \mathrm{C}$ (i.e., 27.12-25) corresponds to the average energy consumption of $15.32 \mathrm{kWh}$ (Table 4). Therefore, energy consumption per $1{ }^{\circ} \mathrm{C}$ cooling equates to $7.23 \mathrm{kWh}(=15.32 / 2.12)$. Similarly, energy consumption per $1{ }^{\circ} \mathrm{C}$ cooling during Period 3 equates to $5.40 \mathrm{kWh}$ (i.e., $9.23 /(26.71-25)$ ).

Table 4. Energy Consumption per $1{ }^{\circ} \mathrm{C}$ Cooling during Period 2 (Vents closed, Shade screens open) and Period 3 (Vents open, Shade screen closed).

\begin{tabular}{cccccccc}
\hline \multirow{2}{*}{ Period } & \multicolumn{2}{c}{ The Temperature at Gutter Level $\left({ }^{\circ} \mathbf{C}\right)$} & \multicolumn{3}{c}{ Cooling Energy Consumption (kWh) } \\
\cline { 2 - 8 } & $\begin{array}{c}\text { Average } \\
\text { Temp_B }\end{array}$ & Min Temp_B & Max Temp_B & $\begin{array}{c}\text { Hourly } \\
\text { Average }\end{array}$ & $\begin{array}{c}\text { Hourly } \\
\text { Minimum }\end{array}$ & $\begin{array}{c}\text { Hourly } \\
\text { Maximum }\end{array}$ & $\begin{array}{c}\text { Per 1 }{ }^{\circ} \mathbf{C} \\
\text { Cooling (kWh) }\end{array}$ \\
\hline Period 2 & 27.12 & 25.61 & 28.43 & 15.32 & 2.92 & 26.96 & 7.23 \\
Period 3 & 26.71 & 25.13 & 28.24 & 9.23 & 1.89 & 14.00 & 5.40 \\
\hline
\end{tabular}

It was noted from statistical analysis (Table A4) that the average temperature and the range during the two experimental periods are similar. However, cooling energy consumption is significantly different under two different combinations of vents and shade screen statuses (open/closed). When energy consumption per $1{ }^{\circ} \mathrm{C}$ cooling is compared, on average Period 3 consumes $2 \mathrm{kWh}$ less than that in Period 3 . When this saving of $2 \mathrm{kWh}$ per $1{ }^{\circ} \mathrm{C}$ cooling is considered from the perspective of an overall temperature profile of the compartment and outside temperature, it is significant since the temperature difference between gutter level and outside during day time (08:00 to 16:00) is significant (Tables A2 and A3). This saving of $2 \mathrm{kWh}$ per $1{ }^{\circ} \mathrm{C}$ cooling will lead to a significant amount of energy savings over many fully enclosed greenhouse vegetable crops subject to (i) warmer outside weather conditions and (ii) greenhouse crops with longer crop cycles such as 277 days of capsicum crop [23]. Therefore, total savings of cooling energy consumption should be evaluated, based on savings of each day of the entire crop cycle, taking into consideration of temperature profile of the facility and the outside temperature during the whole crop cycle.

It was noted from cooling energy consumption recorded during $8 \mathrm{~h}$ (08:00 to 16:00) using two sets of experiments (Periods 2 and 3 ) that daily cooling energy consumption is similar, including no energy consumptions in early hourly periods (08:00 to 09:00 on day 1, 08:00 to 10:00 on day 2 and 3 of both Periods 2 and 3 as shown in Table A5 of Appendix C), mainly due to a lower or around $25^{\circ} \mathrm{C}$ recorded at the gutter level. Therefore, further energy savings could be achieved by opening/closing both vents and shade screen at the appropriate times using adjustable settings. For example, the opening of vents could be delayed until the gutter level temperature reaches $25^{\circ} \mathrm{C}$ and thereby avoiding overcooling that would require heating. Since both sets of experiments have the same time slots of no cooling energy consumption recorded (08:00 to 09:00 on one day and 08:00 to 10:00 on two days as shown in Table A5), vents and shade screen could be set open and closed 
respectively at the time that the gutter temperature reaches $25{ }^{\circ} \mathrm{C}$. To estimate the time at which this occurs in the morning, it is assumed that the temperature increases linearly.

Table 5 shows estimated times in the morning and afternoon of over three days of Periods 2 and 3 as a guide for setting the times to open and close vents and shade screen for better cooling energy consumption. Based on the observation of no cooling energy consumption during early times slots and the cooler temperatures outside below $25{ }^{\circ} \mathrm{C}$ (Table A5), it can be assumed that the facility needs heating during these times if the vents are open at 08:00 as per the current experimental settings. Therefore, if vents are set to open only after the gutter level temperature reaches $25^{\circ} \mathrm{C}$, further energy savings could be achieved.

Table 5. Average Temperature of Day 1 (08:00 and 09:00), Days 2 and 3 (08:00 and 10:00) and Estimated Time reaching $25^{\circ} \mathrm{C}$ each day.

\begin{tabular}{cccccc}
\hline \multicolumn{2}{c}{ Day 1 (Periods 2 and 3) } & \multicolumn{2}{c}{ Day 2 (Periods 2 and 3) } & \multicolumn{2}{c}{ Day 3 (Periods 2 and 3) } \\
\hline Time-HRS & Temp_B, ${ }^{\circ} \mathbf{C}$ & Time-HRS & Temp_B, ${ }^{\circ} \mathbf{C}$ & Time-HRS & Temp_B, ${ }^{\circ} \mathbf{C}$ \\
\hline 08:00 & 21.1 & $8: 00$ & 20.89 & $08: 00$ & 20.67 \\
09:00 & 25.66 & $10: 00$ & 26.4 & $10: 00$ & 25.55 \\
08:51 & 25.0 & $9: 29$ & 25.0 & $09: 47$ & 25.0 \\
\hline
\end{tabular}

To estimate energy savings over a normal growth period of the greenhouse crop cycle across five states of Australia, the maximum energy savings that could be achieved are evaluated, based on the savings per ${ }^{\circ} \mathrm{C}$ evaluated from the comparison of periods 2 and 3 . Thus, As shown in Table 6, the estimated cost of energy savings in NSW is shown to be the highest, significantly higher than those of other states. Therefore, these estimates along with other factors could be used as a guide to developing cost-benefit analysis for making decisions on greenhouse operations, particularly energy management.

Table 6. Estimated energy cost savings for the difference between Periods $2(7.23 \mathrm{kWh})$ and $3(5.40 \mathrm{kWh})$ over a 9-month growth period for greenhouses in five states of Australia.

\begin{tabular}{|c|c|c|c|}
\hline State & Wholesale Price per MWh (2020) * & $\begin{array}{l}\text { Estimated Energy Savings in the } \\
\text { WSU Greenhouse, } \$^{\circ} C^{-1}\end{array}$ & $\begin{array}{c}\text { Estimated Energy Savings in a 10-Ha } \\
\text { High-Tech Greenhouse, } \$^{\circ} C^{-1}\end{array}$ \\
\hline VIC & $\$ 40$ & $\$ 19.76$ & $\$ 17,967$ \\
\hline NSW & $\$ 71$ & $\$ 35.08$ & $\$ 31,892$ \\
\hline QLD & $\$ 48$ & $\$ 23.72$ & $\$ 21,561$ \\
\hline SA & $\$ 35$ & $\$ 17.29$ & $\$ 15,721$ \\
\hline TAS & $\$ 46$ & $\$ 22.73$ & $\$ 20,662$ \\
\hline
\end{tabular}

* Australian Energy Regulator, Australian Government. https:/ / www.aer.gov.au, accessed on 13 September 2021.

\section{Discussion}

Sustainable protected cropping is one of the key areas of interest among industry practitioners and researchers in recent years, due to many opportunities and challenges. Several studies have reported different levels of environmental impacts, emphasizing a high level of energy consumption and the need for significant energy savings in protected cropping. In this context, the cost of cooling and heating energy is a major cost (second only to labour costs) for a sustainable business operation [11]. Some studies have reported on both energy use and environmental impacts under different climate conditions, that are confined mainly to tomato, bean, and cucumber production in European countries [24,25]. Some studies on energy use and carbon footprint in protected cropping have shown the positive overall outcome of energy use, environmental impact, and productivity. Energy use for heating to compensate for the greater environmental impact was considered acceptable if productivity increases by $60 \%$ [25] and potential improvements in reducing overall energy use, carbon footprint, and water footprint, through trade-offs between these three indicators [24]. Nevertheless, studies on energy consumption and its environmental impact in the protected cropping environment are relatively scarce. 
In this study, we reported the optimal treatment such as vents open/shade screen closed has less energy load at the rooftop to reduce temperature and cooling energy cost. We found that the significant day-time temperature differences observed from a set of control experiments are directly related to significant differences in energy consumption to maintain the desired temperature inside the greenhouse facility. The effectiveness of vents opening during the day for maintaining the desired temperature is emphasised, which is supported by the evidence that the internal temperature level was influenced by the vents opening-wind speed [26] and ventilation using vents opening replaces warm, internal air with cool, external air [11]. Since the configuration of vents open and shade screen closed (Period 3) was shown to be the most effective configuration in maintaining the desired temperature in the facility during the day, cooling energy consumption during the day could be reduced significantly by adopting adjustable settings of vents opening and shade screen closing, taking into consideration of the temperature profile of the facility and outside temperature. Comparison of energy consumption between two extreme combinations of vents and shade screen positions (i.e., Period 2-vents closed and shade screen open, and Period 3-vents open and the shade screen closed) showed that significant cooling energy saving can be made by the combination of vent open and the shade screen closed during the day time of operations. These results can be used as a guide for developing timeframes for different open/closed combinations of both vents and the shade screen, depending on the measured temperature differences inside the facility and external temperature. The timeframes for vents opening can be used to dynamically set the temperature control of the compartment as a basis for developing specific control approaches [27].

Since vent status (closed/open) contributes significantly to the daily energy consumption, compared to that of shade screen position (closed/open), energy consumption can be made efficient by adjusting the position of vents, based on the temperature captured from the rooftop rather than gutter level. Given the temperature difference between the two levels is significantly different during the Period 2 experiments, adjusting the status of the vent, based on the rooftop level temperature can significantly reduce the energy consumption. It was also found from a comparison of cooling energy consumption between Periods 2 and 3 that hourly energy consumption in Period 3 is significantly less than that in Period 2 (Table A4). The control settings of vents opening and shade screen closing during the day for energy savings could be used to extend the control strategies in greenhouses reported by previous studies [26,28]. Further analysis of energy consumption taking into consideration of temperature profile of the facility and outside temperature under two extreme configuration settings tested (Periods 2 and 3) found that cooling energy consumption can be benchmarked using the cooling energy consumption (kWh) per $1^{\circ} \mathrm{C}$ reduction. It was found that energy consumption per $1^{\circ} \mathrm{C}$ cooling in Periods 2 and 3 are $7.23 \mathrm{kWh}$ and $5.40 \mathrm{kWh}$, respectively. Energy savings of $1.83 \mathrm{kWh}$ per $1^{\circ} \mathrm{C}$ cooling between Periods 2 and 3 can lead to significant overall energy savings at $494.1 \mathrm{kWh}$ per ${ }^{\circ} \mathrm{C}$ over a crop cycle of nine months under warmer weather conditions. It was also found that delaying the operation of opening and closing of vents and shade screen until the gutter level reaches $25{ }^{\circ} \mathrm{C}$ not only makes further savings on cooling energy consumption but also avoids heating of the facility in the morning (e.g., 08:00 to 10:00). This can be used as a basis for estimating overall cooling energy savings during an entire crop cycle and thereby optimal energy management, using the cooling energy consumption recorded in the system, temperature profile, and outside temperature. It was also found that adjustable settings for the opening of vents and closing of shade screens can lead to conserving cooling energy consumption further.

Several studies have considered various aspects, including benchmarking of current practices as the basis for improving the protected cropping industry from the perspectives of energy consumption and environmental impacts [29]. These studies combined energy use, carbon footprint, and water footprint from some comparisons of production situations and crop types [10,30], as well as environmental and economic assessment in cold and warm climates [5], considering environmental impacts from a life-cycle analysis (LCA). 
LCA has been extensively used to assess and compare different situations, including assessing environmental impacts and trade-offs in field and greenhouse production [31] and comparing protected cropping diverse climate and geographical conditions $[1,29,32]$. Some studies have also reported many dimensions of environmental and impact factors in different geographical locations (e.g., Italy, Ontario-Canada, Almeria, Spain, Hungary, and the Netherlands) and various produce (e.g., tomato, cucumber, and lettuce), as well as carbon, water footprints and energy use in a greenhouse [1,24,33]. Although some studies $[10,30,33,34]$ have considered LCA of protected cropping, emphasising the optimum life cycle by shifting the crop cycle, there are very limited studies on energy analysis in protected cropping, taking into consideration of different and adjustable settings for optimum light and ventilation conditions. Here, we demonstrated that the optimal treatment (vents open/shade screen closed) is estimated to make significant cost savings in greenhouse operations, particularly in NSW where the cost savings per ${ }^{\circ} \mathrm{C}$ cooling of a 10 Ha greenhouse is $\$ 31,892$ (Table 6). The significant energy saving by simple adjustment of vents and curtains indicates that the energy savings are net incomes to the growers because there is no new capital investment associated with this cooling strategy proposed in this paper. However, further comprehensive studies on a range of greenhouse crops (e.g., cucumber, eggplant) in a large ( $>1 \mathrm{ha}$ ) commercial greenhouse facility and LCA analysis are required before this cooling strategy can be adopted by the growers.

\section{Conclusions}

The vents-open and shade screen-closed configuration reduced daily cooling energy consumption compared to all other configurations and maintained a uniform and desired temperature throughout the facility. Therefore, activation of vents opening and closing based on adjustable settings using the rooftop level temperature, rather than the current gutter level temperature, could save considerable cooling energy consumption. Furthermore, adjustable settings for the opening of the vents and closing of shade screen, based on the required temperature and tolerance levels, are recommended as the optimal cooling strategy for energy management taking into consideration the type of crop and stage of the crop cycle.

Since cooling, energy consumption in a comparable compartment within the same protected facility is around $2.23 \mathrm{kWh}$ per $1{ }^{\circ} \mathrm{C}$ cooling [23], the potential saving of cooling energy consumption could be significant. Furthermore, significant cost savings can be achieved over a crop cycle of nine months in a large greenhouse under warmer conditions. These research findings can be used as a guide for developing timeframes for adjustable settings of vents and shade screen operation, depending on the measured temperature differences inside the greenhouse and outdoor temperature, the type of crop, and stage of the crop cycle. Although vents opening using the adjustable settings could provide better cooling energy consumption, taking advantage of the warm outside temperature, a longer period of vents opening could have adverse effects on other conditions such as reducing $\mathrm{CO}_{2}$ and humidity level, therefore, selection of the optimal cooling strategy within a holistic approach to energy consumption must also account the impact on other environmental factors, including light, humidity, and $\mathrm{CO}_{2}$ level, which could be cropspecific. To set benchmarking of energy consumption with different combinations of vents/shade screen configuration, experiments need to be carried out during selected crop cycles and extended periods covering the warmer season. Since the measurement period of this research is limited to a very short period, verification through long-term measurement is required in future studies for generalising these research findings with a view developing developing developing timeframes for adjustable settings of vents and shade screen operations under protected cropping. Furthermore, future research studies need to consider the external wind pressure conditions that cause the chimney effect to affect the temperature distribution inside the greenhouse, given that these conditions are not considered in this research study. 
Author Contributions: Conceptualization, P.S. and Y.-C.L.; Data curation, C.M. and W.L.; Formal analysis, P.S. and Y.-C.L.; Funding acquisition, Z.-H.C. and D.T.T.; Investigation, P.S. and Y.-C.L.; Methodology, C.M.; Project administration, D.T.T. and Z.-H.C.; Resources, P.S., Z.-H.C., S.C. and D.T.T.; Supervision, P.S. and Y.-C.L.; Validation, C.M., S.C., W.L., Z.-H.C. and D.T.T.; Visualization, P.S. and Y.-C.L.; Writing-original draft, P.S. and Y.-C.L.; Writing-review \& editing, Z.-H.C., D.T.T., C.M., S.C. and W.L. All authors have read and agreed to the published version of the manuscript.

Funding: The study is funded by Horticulture Innovation Australia projects (MT13041, VG16070, VG17003, LP18000) and contributes to the objectives of the Cooperative Research Centre project Future Food Systems.

Acknowledgments: The research work at the WSU greenhouse facility was funded by Hort Innovation projects (MT13041, VG17003, LP18000). We thank Terry Lin (Western Sydney University) for providing the Priva climate parameter description.

Conflicts of Interest: The authors declare no conflict of interest.

\section{Appendix A}

Control Parameters of the Greenhouse Facility (S40) at the Western Sydney University.

Table A1. List of all parameters controlled by Priva.

\begin{tabular}{|c|c|}
\hline Parameter & Priva Variable Name \\
\hline Timestamp & Timestamp (dd/mm/yy hh:mm:ss) \\
\hline \multirow{2}{*}{ Measured Air Temperature } & Meas grh temp $\left({ }^{\circ} \mathrm{C}\right)$ \\
\hline & Des setpoint temp $\left({ }^{\circ} \mathrm{C}\right)$ \\
\hline \multirow{2}{*}{ Shade Screen } & Act shade screen func. $(0,1,2)$ \\
\hline & Meas shade screen $(\%)$ \\
\hline \multirow{3}{*}{$\mathrm{CO}_{2}$} & Meas $\mathrm{CO}_{2}$ conc (ppm) \\
\hline & Set conc $(\mathrm{ppm})$ \\
\hline & Set vent temp $\left({ }^{\circ} \mathrm{C}\right)$ \\
\hline \multirow{3}{*}{ Venting Temperature } & Vent temp $\left({ }^{\circ} \mathrm{C}\right)$ \\
\hline & Meas vent $\mathrm{t}\left({ }^{\circ} \mathrm{C}\right)$ \\
\hline & Base vent $\mathrm{t}\left({ }^{\circ} \mathrm{C}\right)$ \\
\hline \multirow{7}{*}{ Vent Aperture } & Min lee $(\%)$ \\
\hline & Min wind (\%) \\
\hline & Max lee $(\%)$ \\
\hline & Max wind (\%) \\
\hline & Meas lee $(\%)$ \\
\hline & Meas wind (\%) \\
\hline & Act vent pos. (\%) \\
\hline \multirow{6}{*}{ Heating System (Gas Heater With Pipes) } & Heat temp $\left({ }^{\circ} \mathrm{C}\right)$ \\
\hline & Set heat temp $\left({ }^{\circ} \mathrm{C}\right)$ \\
\hline & Current (A) \\
\hline & Meter reading $(\mathrm{kW})$ \\
\hline & Total (kWh) \\
\hline & Pump active $(1,2)$ \\
\hline \multirow{4}{*}{ Cooling System (Mechanical Cooler With Pipes) } & Current (A) \\
\hline & Meter reading $(\mathrm{kW})$ \\
\hline & Total (kWh) \\
\hline & ATS active strat $(1,2)$ \\
\hline \multirow{2}{*}{ Humidity Deficit } & Used HD meas. $\left(\mathrm{g} \mathrm{m}^{-3}\right)$ \\
\hline & Des HD $\left(\mathrm{g} \mathrm{m}^{-3}\right)$ \\
\hline \multirow{2}{*}{ Relative Humidity } & Used RH meas. (\%) \\
\hline & Des RH (\%) \\
\hline \multirow{3}{*}{$\begin{array}{l}\text { Photosynthetically-active } \\
\text { Radiation }\end{array}$} & PAR Control $\left(\mu \mathrm{mol} \mathrm{s}{ }^{-1} \mathrm{~m}^{-2}\right)$ \\
\hline & Used PAR $\left(\mu \mathrm{mol} \mathrm{s}{ }^{-1} \mathrm{~m}^{-2}\right)$ \\
\hline & PAR sum $\left(\mathrm{mol} \mathrm{m}^{-2}\right)$ \\
\hline \multirow{3}{*}{ Irrigation/Fertigation } & $24 \mathrm{~h}$ dose $\left(\mathrm{L} \mathrm{m}^{-2}\right)$ \\
\hline & $24 \mathrm{~h}$ drain $\left(\mathrm{L} \mathrm{m}^{-2}\right)$ \\
\hline & Meas EC drain $\left(\mathrm{mS} \mathrm{cm}^{-2}\right)$ \\
\hline
\end{tabular}




\section{Appendix B}

Key Descriptive Statistics and ANOVA Test Results of Temperature and Cooling Energy Consumption.

Table A2. Descriptive Statistics of Temperature Profile and ANOVA Test Statistics (Period 2).

\begin{tabular}{|c|c|c|c|c|c|c|}
\hline \multicolumn{7}{|c|}{ Descriptive Statistics } \\
\hline Variable & Count & Sum & Average & Variance & & \\
\hline Temp_B, ${ }^{\circ} \mathrm{C}$ & 27 & 710 & 26.28 & 4.51 & & \\
\hline Temp_T, ${ }^{\circ} \mathrm{C}$ & 27 & 809 & 29.95 & 29.33 & & \\
\hline Temp_Outside, ${ }^{\circ} \mathrm{C}$ & 27 & 469.6 & 17.39 & 16.44 & & \\
\hline \multicolumn{7}{|c|}{ ANOVA-BetweenTemp_B and Temp_T } \\
\hline Source of Variation & $S S$ & $d f$ & MS & $F$ & p-value & F crit \\
\hline Between Groups & 181.66 & 1 & 181.66 & 10.734 & 0.0018 & 4.03 \\
\hline Within Groups & 879.99 & 52 & 16.92 & & & \\
\hline \multicolumn{7}{|c|}{ ANOVA-Between Temp_B and Temp_Outside } \\
\hline Source of Variation & SS & $d f$ & MS & $F$ & p-value & F crit \\
\hline Between Groups & 1066 & 1 & 1066 & 101.77 & 0.00000 & 4.03 \\
\hline Within Groups & 544.73 & 52 & 10.48 & & & \\
\hline
\end{tabular}

Table A3. Descriptive Statistics of Temperature Profile and ANOVA Test Statistics (Period 3).

\begin{tabular}{|c|c|c|c|c|c|c|}
\hline \multicolumn{7}{|c|}{ Descriptive Statistics } \\
\hline Variable & Count & Sum & Average & Variance & & \\
\hline Temp_B, ${ }^{\circ} \mathrm{C}$ & 27 & 700 & 25.92 & 4.71 & & \\
\hline Temp_T, ${ }^{\circ} \mathrm{C}$ & 27 & 755 & 27.97 & 30.56 & & \\
\hline Temp_Outside, ${ }^{\circ} \mathrm{C}$ & 27 & 459.4 & 17.01 & 11.50 & & \\
\hline \multicolumn{7}{|c|}{ ANOVA-Between Temp_B and Temp_T } \\
\hline Source of Variation & $S S$ & $d f$ & MS & $F$ & p-value & F crit \\
\hline Between Groups & 56.65 & 1 & 56.67 & 3.21 & 0.08 & 4.03 \\
\hline Within Groups & 917.07 & 52 & 17.64 & & & \\
\hline \multicolumn{7}{|c|}{ ANOVA-Between Temp_B and Temp_Outside } \\
\hline Source of Variation & SS & $d f$ & MS & $F$ & p-value & F crit \\
\hline Between Groups & 1070.63 & 1 & 1070.63 & 132.04 & 0.0000 & 4.03 \\
\hline Within Groups & 421.64 & 52 & 8.11 & & & \\
\hline
\end{tabular}

Table A4. Descriptive Statistics of Cooling Energy Consumption and ANOVA Test Statistics (Period 2 vs. Period 3).

\begin{tabular}{|c|c|c|c|c|c|c|}
\hline \multicolumn{7}{|c|}{ Descriptive Statistics } \\
\hline $\begin{array}{l}\text { Variable } \\
\text { Hourly Energy }\end{array}$ & Count & Sum & Average & Variance & & \\
\hline $\begin{array}{l}\text { Consumption } \\
\text { (kWh)-Period } 2 \\
\text { Hourly Energy }\end{array}$ & 27 & 337 & 12.48 & 80.13594 & & \\
\hline $\begin{array}{l}\text { Consumption } \\
\text { (kWh)_Period } 3 \\
\text { ANOVA }\end{array}$ & 27 & 203 & 7.52 & 22.28928 & & \\
\hline Source of Variation & SS & $d f$ & MS & $F$ & p-value & F crit \\
\hline
\end{tabular}

\section{Appendix C}

Temperature Profile of the Facility and Hourly Cooling Energy Consumption. 
Table A5. Temperature at gutter and rooftop levels and hourly cooling energy consumption, from 08:00 to 16:00 during Periods 2 and 3 .

\begin{tabular}{|c|c|c|c|c|c|c|}
\hline \multirow[b]{2}{*}{ Time } & \multicolumn{3}{|c|}{ Period 2 (23-25 May 2021) } & \multicolumn{3}{|c|}{ Period 3 (26-28 May 2021) } \\
\hline & Temp_B, ${ }^{\circ} \mathrm{C}$ & Temp_T, ${ }^{\circ} \mathrm{C}$ & $\begin{array}{c}\text { Hourly Cooling } \\
\text { Energy } \\
\text { Consumption (kWh) }\end{array}$ & Temp_B, ${ }^{\circ} \mathbf{C}$ & Temp_T, ${ }^{\circ} \mathrm{C}$ & $\begin{array}{c}\text { Hourly Cooling } \\
\text { Energy } \\
\text { Consumption (kWh) }\end{array}$ \\
\hline 08:00 & 20.67 & 20.60 & 0.00 & 21.52 & 23.54 & 0.00 \\
\hline 09:00 & 25.71 & 26.17 & 2.92 & 25.61 & 26.98 & 1.89 \\
\hline 10:00 & 26.17 & 28.64 & 9.08 & 25.83 & 31.77 & 9 \\
\hline $11: 00$ & 27.84 & 34.80 & 22.88 & 26.46 & 34.90 & 13 \\
\hline $12: 00$ & 27.86 & 36.69 & 22 & 26.78 & 34.72 & 13.06 \\
\hline 13:00 & 28.33 & 37.28 & 23 & 27.45 & 33.72 & 14 \\
\hline $14: 00$ & 27.89 & 33.59 & 20.08 & 27.64 & 30.57 & 13 \\
\hline $15: 00$ & 27.27 & 29.06 & 15 & 27.86 & 25.03 & 9.05 \\
\hline $16: 00$ & 26.20 & 25.95 & 8.04 & 26.03 & 20.46 & 7 \\
\hline 08:00 & 21.64 & 21.27 & 0 & 20.14 & 20.09 & 0 \\
\hline 09:00 & 27.32 & 30.28 & 9.96 & 25.18 & 25.84 & 0 \\
\hline $10: 00$ & 27.57 & 33.82 & 22 & 25.23 & 31.94 & 8.95 \\
\hline $11: 00$ & 25.76 & 34.28 & 5.04 & 26.29 & 35.04 & 7.05 \\
\hline $12: 00$ & 27.57 & 34.75 & 20.88 & 26.90 & 36.46 & 11 \\
\hline $13: 00$ & 27.25 & 33.41 & 17.08 & 28.19 & 35.60 & 13.84 \\
\hline $14: 00$ & 26.98 & 30.74 & 16 & 27.77 & 32.25 & 9.11 \\
\hline $15: 00$ & 25.61 & 25.89 & 4.04 & 27.59 & 25.21 & 8 \\
\hline $16: 00$ & 24.37 & 23.43 & 0 & 25.42 & 19.80 & 4.05 \\
\hline 08:00 & 21.19 & 20.12 & 0 & 20.14 & 20.00 & 0 \\
\hline 09:00 & 25.01 & 24.91 & 0 & 25.25 & 25.26 & 0 \\
\hline $10: 00$ & 25.98 & 26.81 & 9 & 25.13 & 28.11 & 9 \\
\hline $11: 00$ & 27.40 & 33.27 & 16.92 & 26.24 & 29.55 & 7 \\
\hline $12: 00$ & 28.06 & 38.13 & 26.96 & 26.49 & 30.51 & 12.95 \\
\hline $13: 00$ & 28.43 & 37.58 & 24.04 & 28.24 & 29.73 & 11.96 \\
\hline $14: 00$ & 27.99 & 33.29 & 21.04 & 27.47 & 27.06 & 8.09 \\
\hline $15: 00$ & 27.45 & 29.16 & 14.04 & 27.62 & 22.79 & 6.95 \\
\hline $16: 00$ & 25.99 & 24.94 & 7 & 25.34 & 18.22 & 5.05 \\
\hline
\end{tabular}

\section{References}

1. Torrellas, M.; Antón, A.; Ruijs, M.; Victoria, N.G.; Stanghellini, C.; Montero, J.I. Environmental and economic assessment of protected crops in four European scenarios. J. Clean. Prod. 2012, 28, 45-55. [CrossRef]

2. Bambara, J.; Athienitis, A.K. Energy and economic analysis for the design of greenhouses with semi-transparent photovoltaic cladding. Renew. Energy 2019, 131, 1274-1287. [CrossRef]

3. Geilfus, C.-M. Protected Cropping in Horticulture. In Controlled Environment Horticulture; Springer: Cham, Switzerland, 2019; pp. 7-17.

4. Gruda, N.; Bisbis, M.; Tanny, J. Impacts of protected vegetable cultivation on climate change and adaptation strategies for cleaner production-A review. J. Clean. Prod. 2019, 225, 324-339. [CrossRef]

5. Del Borghi, A.; Gallo, M.; Strazza, C.; Del Borghi, M. An evaluation of environmental sustainability in the food industry through Life Cycle Assessment: The case study of tomato products supply chain. J. Clean. Prod. 2014, 78, 121-130. [CrossRef]

6. Islam, M.S.; Wong, A.T. Climate change and food in/security: A critical nexus. Environments 2017, 4, 38. [CrossRef]

7. Castilla, N.; Montero, J.I. Environmental control and crop production in Mediterranean greenhouses. In Proceedings of the International Workshop on Greenhouse Environmental Control and Crop Production in Semi-Arid Regions 797, Tucson, AZ, USA, 20-24 October 2008; pp. 25-36.

8. Torrellas, M.; Antón, A.; López, J.C.; Baeza, E.J.; Parra, J.P.; Muñoz, P.; Montero, J.I. LCA of a tomato crop in a multi-tunnel greenhouse in Almeria. Int. J. Life Cycle Assess. 2012, 17, 863-875. [CrossRef]

9. Flores, H.; Villalobos, J.R.; Ahumada, O.; Uchanski, M.; Meneses, C.; Sanchez, O. Use of supply chain planning tools for efficiently placing small farmers into high-value, vegetable markets. Comput. Electron. Agric. 2019, 157, 205-217. [CrossRef]

10. Bartzas, G.; Zaharaki, D.; Komnitsas, K. Life cycle assessment of open field and greenhouse cultivation of lettuce and barley. Inf. Process. Agric. 2015, 2, 191-207. [CrossRef]

11. Rabbi, B.; Chen, Z.H.; Sethuvenkatraman, S. Protected cropping in warm climates: A review of humidity control and cooling methods. Energies 2019, 12, 2737. [CrossRef] 
12. Stanhill, G. The energy cost of protected cropping: A comparison of six systems of tomato production. J. Agric. Eng. Res. 1980, 25, 145-154. [CrossRef]

13. Khoshnevisan, B.; Shariati, H.M.; Rafiee, S.; Mousazadeh, H. Comparison of energy consumption and GHG emissions of open field and greenhouse strawberry production. Renew. Sustain. Energy Rev. 2014, 29, 316-324. [CrossRef]

14. Yildizhan, H. Energy, exergy utilization and CO2 emission of strawberry production in greenhouse and open field. Energy 2018, 143, 417-423. [CrossRef]

15. Golzar, F.; Heeren, N.; Hellweg, S.; Roshandel, R. A novel integrated framework to evaluate greenhouse energy demand and crop yield production. Renew. Sustain. Energy Rev. 2018, 96, 487-501. [CrossRef]

16. Chavan, S.G.; Maier, C.; Alagoz, Y.; Filipe, J.C.; Warren, C.R.; Lin, H.; Jia, B.; Loik, M.E.; Cazzonelli, C.I.; Chen, Z.H.; et al. Light-limited photosynthesis under energy-saving film decreases eggplant yield. Food Energy Secur. 2020, 9, e245. [CrossRef]

17. He, X.; Maier, C.; Chavan, S.G.; Zhao, C.-C.; Alagoz, Y.; Cazzonelli, C.; Ghannoum, O.; Tissue, D.T.; Chen, Z.-H. Light-altering cover materials and sustainable greenhouse production of vegetables: A review. Plant Growth Regul. 2021, 95, 1-17. [CrossRef]

18. Zhao, C.; Chavan, S.; He, X.; Zhou, M.; Cazzonelli, C.I.; Chen, Z.-H.; Tissue, D.T.; Ghannoum, O. Smart glass impacts stomatal sensitivity of greenhouse Capsicum through altered light. J. Exp. Bot. 2021, 72, 3235-3248. [CrossRef]

19. Lee, S.; Kim, S.-H.; Woo, B.-K.; Son, W.-T.; Park, K.-S. A study on the energy efficiency improvement of greenhouses-with a focus on the theoretical and experimental analyses. J. Mech. Sci. Technol. 2012, 26, 3331-3338. [CrossRef]

20. Shen, Y.; Wei, R.; Xu, L. Energy Consumption Prediction of a Greenhouse and Optimization of Daily Average Temperature. Energies 2018, 11, 65. [CrossRef]

21. Liu, Y.; Høgh-Jensen, H.; Egelyng, H.; Langer, V. Energy efficiency of organic pear production in greenhouses in China. Renew. Agric. Food Syst. 2010, 25, 196-203. [CrossRef]

22. Moghaddam, P.R.; Feizi, H.; Mondani, F. Evaluation of Tomato Production Systems in Terms of Energy Use Efficiency and Economical Analysis in Iran. Not. Sci. Biol. 2011, 3, 58-65. [CrossRef]

23. Samaranayake, P.; Liang, W.; Chen, Z.-H.; Tissue, D.; Lan, Y.-C. Sustainable Protected Cropping: A Case Study of Seasonal Impacts on Greenhouse Energy Consumption during Capsicum Production. Energies 2020, 13, 4468. [CrossRef]

24. Almeida, J.; Achten, W.; Verbist, B.; Heuts, R.F.; Schrevens, E.; Muys, B. Carbon and water footprints and energy use of greenhouse tomato production in Northern Italy. J. Ind. Ecol. 2014, 18, 898-908. [CrossRef]

25. Zarei, M.J.; Navab, K.; Afshin, M. Life cycle environmental impacts of cucumber and tomato production in open-field and greenhouse. J. Saudi Soc. Agric. Sci. 2017, 18, 249-255. [CrossRef]

26. Zhang, S.; Guo, Y.; Zhao, H.; Wang, Y.; Chow, D.; Fang, Y. Methodologies of control strategies for improving energy efficiency in agricultural greenhouses. J. Clean. Prod. 2020, 274, 122695. [CrossRef]

27. Benni, S.; Tassinari, P.; Bonora, F.; Barbaresi, A.; Torreggiani, D. E_cacy of greenhouse natural ventilation: Environmental monitoring and CFD simulations of a study case. Energy Build. 2016, 125, 276-286. [CrossRef]

28. Su, Y.; Xu, L.; Goodman, E.D. Greenhouse climate fuzzy adaptive control considering energy saving. Int. J. Control Autom. Syst. 2017, 15, 1936-1948. [CrossRef]

29. Dias, G.M.; Ayer, N.W.; Khosla, S.; Van Acker, R.; Young, S.B.; Whitney, S.; Hendricks, P. Life cycle perspectives on the sustainability of Ontario greenhouse tomato production: Benchmarking and improvement opportunities. J. Clean. Prod. 2017, 140, 831-839. [CrossRef]

30. Payen, S.; Basset-Mens, C.; Perret, S. LCA of local and imported tomato: An energy and water trade-off. J. Clean. Prod. 2015, 87, 139-148. [CrossRef]

31. Martínez-Blanco, J.; Muñoz, P.; Antón, A.; Rieradevall, J. Assessment of tomato Mediterranean production in open-field and standard multi-tunnel greenhouse, with compost or mineral fertilizers, from an agricultural and environmental standpoint. $J$. Clean. Prod. 2011, 19, 985-997. [CrossRef]

32. Bojacá, C.R.; Wyckhuys, K.; Schrevens, E. Life cycle assessment of Colombian greenhouse tomato production based on farmer-level survey data. J. Clean. Prod. 2014, 69, 26-33. [CrossRef]

33. Cellura, M.; Ardente, F.; Longo, S. From the LCA of food products to the environmental assessment of protected crops districts: A case-study in the south of Italy. J. Environ. Manag. 2012, 93, 194-208. [CrossRef]

34. Blengini, G.A.; Busto, M. The life cycle of rice: LCA of alternative agri-food chain management systems in Vercelli (Italy). J. Environ. Manag. 2009, 90, 1512-1522. [CrossRef] [PubMed] 